\title{
Social value of Russian criminal procedure law in modern conditions: compensatory approach
}

\author{
Svetlana Kurbatova* \\ Law Institute, Krasnoyarsk State Agrarian University, 660049 Krasnoyarsk, Russia
}

\begin{abstract}
The paper addresses some aspects of the compensatory approach in criminal proceedings in the context of the social value of law, which is critical in ensuring the rights and interests of participants with disabilities in criminal proceedings. The legal mechanisms established in criminal proceedings should aim at ensuring equal conditions for all participants in criminal proceedings in terms of access to legal and fair justice. The author believes that there is a need to draw attention to the legal status of participants with disabilities in criminal proceedings. It is necessary to recognize socially vulnerable categories of persons (persons with disabilities) as the participants with special legal status in criminal proceedings. A compensatory approach should also be adopted in the implementation of the legal regulation of the participation of such persons in criminal proceedings. It is necessary to "reach", "raise" the possibility of exercising their procedural rights to the level of other participants. The procedural mechanism should contain a list of general and special rights and obligations of these persons, as well as guarantees for their implementation. This approach is compensatory and reflects the social value of law in criminal proceedings. The author considers the consolidation of the compensatory approach as the realization of the idea of a social state and international socially significant values to ensure equal and fair criminal proceedings.
\end{abstract}

\section{Introduction}

There is now a steady global trend towards increasing the value of law in general and mechanisms for regulating relationships involving persons with disabilities. In traditional social fields, such as health, social security and education, these processes are more intensive and obvious, but in the field of criminal proceedings this transformation is quite slow [1]. This was the result of the development of the concept of a social state, the realization of the social value of law [2, 3 ], the consolidation of new socially significant ideas in international legal norms, which entailed a change in the modern understanding of the social essence of the rule of law [4-6]. General international legal provisions on the legal status of persons with disabilities should be developed and implemented in national criminal procedure legislation $[7,8]$.

Criminal procedure is a normative and established universal systemic form of implementing legal relations between participants in criminal proceedings at all stages:

- initiation of a criminal case (or refusal to initiate a criminal case);

- inquiry and preliminary investigation of criminal cases;

- referral of a criminal case to court (or termination of proceedings in case);

- acceptance of the criminal case by the court and preparation for its consideration;
- hearing of the criminal case on the merits by the court of first instance;

- judicial proceedings in the courts of appeal, cassation and supervision concerning complaints against court decisions;

- resolving issues related to the execution of the sentence.

On the one hand, this ensures the stability of the administration of justice and reflects the public nature of the legal regulation of criminal procedure. On the other hand, this prevents the free introduction of new international legal social and humanistic ideas into criminal proceedings [9], which may adversely affect the rights of persons with disabilities in criminal proceedings [10].

\section{Problem statement}

One manifestation of the social value of law is to ensure the equality of rights and opportunities for people. Besides, there is a need to distinguish the concepts of the "equality of rights" and "equality". The latter is legally reflected in the UN Declaration on Race and Racial Prejudice (1978), which enshrines the idea of racial equality of all peoples of the world; UN Universal Declaration on the Human Genome and Human Rights (1997), Convention for the Protection of Human Rights and Dignity of the Human Being with regard to the Application of Biology and Medicine; Convention on Human Rights and Biomedicine (1997), UN Universal

Corresponding author: sveta_kurbatova@mail.ru 
Declaration on Bioethics and Human Rights (2005), which formed an understanding of the equality of people regardless of their genetic characteristics, and other international legal acts. In this case, a person is considered as a certain especially significant and therefore international especially protected social value. In the future, this is specified in relation to the specifics of individual legal relations. According to L.D. Voevodin, the equality of rights is one of the manifestations of social equality of people [11].

This view is supported by S.A. Avakyan noting that legal and physical (actual) equality cannot be mixed and D. Bunyak, who believes that the "equality of people" in the plane of jurisprudence should not be understood literally, since "people cannot be absolutely equal (except for theoretical idealized situations), but can be endowed with the same rights (first of all, to life) and opportunities - i.e. equal - due to the law and high level of legal consciousness in the society" [12], V.E. Chirkin arguing that "people are unequal in their physical and mental capabilities, in their standard of living, in other characteristics, and in this regard no right is able to equalize them. The Constitution can only grant equal rights, equal legal (but not actual) opportunities to enjoy them, as well as establish equal obligations for all" [13]. In the most general form, the equality of rights is "officially recognized equality of citizens before the state, law, court" [14].

However, these formulations regarding the equality of people do not ensure the implementation of modern ideas about man, which, although numerous (humans study anthropology, biology, genealogy, genogeography, history, linguistics, medicine, psychology, cultural studies, sociology, philosophy, ethnography, ethology, jurisprudence and other sciences), but nevertheless proceed from the statement of the fact that a man is not just a representative of biological science; a whole set of characteristics makes epy Man, among which we need to emphasize the cognitive functions of the brain: ability to understand, perceive, realize, study, learn and process external information, being the activity of the "central nervous system - the highest nervous activity, without which the personality of a person is lost" [15], which occurs under the influence of society [16], creating the prerequisites for his participation in society, including as a participant in legal relations.

Accordingly, there is a biological and social essence of man; the first created by nature, the second - by society [17]. To be able to fully exist as a biological species, a person must have adequate biological capabilities (hands, legs, speech, vision, hearing, internal organs, etc.). But not always and not everyone has those parts of the body in full and the organs that are genetically embedded in nature; or although present, but do not function properly. Then society comes to the rescue, first of all in the person of the state, which, being a complex and multi-level social institution, covering the main subsystems of society [18], carries out social care for its population, and especially for those persons who cannot take care of themselves independently [19].

This is all important and should be taken into account when implementing legal regulation in certain areas of public relations, including in the field of criminal proceedings.

The legal mechanisms enshrined in the Russian criminal procedure should be aimed at ensuring equal opportunities for all participants in criminal proceedings to have access to legal and fair justice. According to the authors, it is necessary to distinguish and legislate a special category of participants in criminal proceedings "persons with disabilities". This is a logical development of understanding of the essence of the social rule of law at the present stage (to which, according to the Constitution of the Russian Federation, Russia belongs) and giving special status to a socially vulnerable group of persons, as enshrined in the norms of the international law [20].

To this end, it is necessary to develop and establish a conceptual and categorical apparatus in the law, to formulate special rights of this group of persons, guarantees for their provision and procedural mechanisms for their implementation.

It should be noted that at the moment this mechanism in the science of the Russian criminal process has not been sufficiently studied, and the current Russian criminal procedural legislation is not systematically fixed at all: there is no special chapter in the the Code of Criminal Procedure of the Russian Federation (CCP RF) that regulates the peculiarities of criminal proceedings involving persons with disabilities.

We believe that this mechanism should include the following:

- list of general and special rights of these persons, as well as procedural guarantees for their realization; at the same time, the subjects of criminal procedural legal relations exercising state power should be entrusted with a set of procedural duties corresponding to these rights;

- procedural order for the resolution of issues related to the protection of the rights of persons with disabilities;

- legal consequences of non-compliance with these requirements of the law.

Moreover, it is necessary to be aware of the possibility of abuse by the participants in criminal proceedings of their procedural rights and suggest to warn them about the legal consequences of such abuses as measures aimed at preventing them when explaining the rights of participants with disabilities.

The combination of the above provisions, on the one hand, is aimed at ensuring the rights of this group of participants in criminal proceedings, on the other hand, they are designed to ensure the legalization of criminal procedural evidence obtained during investigative and judicial actions involving persons with disabilities in strict compliance with the requirements of the law, taking into account the proposed set of procedural measures.

According to the authors, the implementation of these proposals will make it possible to fully solve the problems of Russian criminal proceedings while respecting the rights of all its participants, including persons with disabilities, in accordance with the provisions of the international law [21]. 


\section{Scope of research}

The subject of the study is as follows:

- value of Russian criminal procedure law as a universal regulatory tool of public relations in the field of criminal proceedings;

- need to establish the legal status of persons with disabilities being the participants in criminal proceedings;

- social value of criminal procedure law, which is expressed, firstly, in the possibility of settling criminal procedure relations with the participation of persons with limited abilities, and secondly, in the consolidation of legal compensatory mechanisms in relation to socially vulnerable persons being the participants in criminal proceedings.

\section{Purpose of study and research methods}

The purpose of this study is to analyze, through a compensatory approach, the value of Russian criminal procedure law as a social regulator of criminal procedure relations involving disabled persons as a category of socially vulnerable persons by consolidating procedural mechanisms for the realization of their rights as the participants in criminal proceedings.

The study was carried out using general scientific and private-scientific methods. Theoretical methods included analysis, synthesis, deduction, induction, etc. The empirical methods, such as the study of the sources of information, interviewing and polling, were used.

\section{Results}

In the context of the modern transformation of criminal forms of judicial proceedings the value of law as a universal, systemic, regulatory and balanced social regulator of social relations in the field of criminal proceedings acquires a special value and increases routinely [22].

The role of the criminal procedure law is most pronounced in ensuring the rights of participants in criminal proceedings and establishes the mechanisms for their implementation.

These mechanisms are primarily aimed at real security of the rights of participants in criminal proceedings.

Special importance should be given to ensuring the rights of persons with disabilities, since they are socially vulnerable and, in most cases, without the involvement of appropriate specialists, cannot fully defend their interests. In particular, this concerns the abilities of the hearing impaired people to fully perceive speech information, the visually impaired - to personally get acquainted with the materials of the criminal case, persons with disabilities - to appear on time when required by officials; persons unable to speak - to transmit information correctly without the help of sign language interpreters, etc.
In the framework of the questionnaire conducted by the author in 2020, 62 investigators of the Investigation Committee of the Russian Federation, 48 investigators and interrogators of law enforcement agencies, as well as 164 judges of the courts of general jurisdiction of the Siberian Federal District on the issues related to the topic of this study, to the question "Do you consider it sufficient to reflect modern ideas about the essence of the social state in the text of the Code of Criminal Procedure of the Russian Federation, despite the fact that the code does not contain compensatory norms that would equalize the legal status of participants in criminal proceedings from among persons with limited cognitive abilities (persons with disabilities, persons of older age groups, persons with mental disorders, severe forms of chronic diseases, etc.)" 54; 38; 66\% of participants answered "yes", respectively, according to the above questionnaire groups.

In their comments in the sections where they were asked to clarify their opinion on the introduction of additional procedural guarantees into the Code of Criminal Procedure of the Russian Federation the respondents indicated, in particular, the following:

- complicates the process;

- proceedings in the case will be too long;

- reasonable period of legal proceedings will be violated;

- additional difficulties in work will be created, etc.

A survey of defenders of suspects, accused, as well as persons who participated as representatives (victims, civil plaintiff, etc.) showed that more than $90 \%$ of respondents do not consider it sufficient to reflect modern ideas about the essence of the social state in the text of the Code of Criminal Procedure.

The above generalizations of the questionnaires of law enforcement officials and the judicial system do not indicate their personal qualities, not their unwillingness to somehow help, support persons who cannot independently exercise their rights and properly protect their interests. This raises a different issue that goes beyond the scope of the present study, but nevertheless seems relevant to it. We are talking about the problems of overcoming the resistance of most personnel of various bodies, firms, organizations to introduce any changes that affect the usual rhythm and format of work (service). As for the personal characteristics of the analyzed respondents, it is noteworthy to highlight the expression of social responsibility among the majority of body employees to the question:

"Do you support the idea of revising the provisions of the existing procedural institution of participants in Russian criminal proceedings carried out on the basis of a cognitive approach given that this will be:

- to comply with the existing international legislation and a modern understanding of the essence of the social state;

- to promote the realization of such principles of law as legality, humanity, justice, state recognition, observance and protection of human rights and freedoms, etc.; 
- to equalize the legal status of participants from among persons with different cognitive capabilities", more than $80 \%$ of participants answered positively.

We believe that it is necessary to establish a compensatory mechanism of a universal nature in the norms of Russian criminal procedure legislation, reflecting the social value of law, and aimed at achieving general legal ideas of equality and justice in the field of criminal proceedings.

Accordingly, in order to adopt a compensatory approach in criminal proceedings, it is necessary:

1) to formulate a general, basic idea of ensuring the rights of participants from among persons with disabilities and affirm it as a principle of criminal proceedings (we propose the principle of the equality of rights of participants in criminal proceedings, in the content of the legal norm of which it is a separate part to prescribe the use of a compensatory approach to equalizing the legal status of participants with disabilities);

2) in a separate chapter:

- to establish the concept and content of criminal procedure;

- to prescribe the grounds and procedure for recognizing participants in criminal proceedings from among persons with disabilities as subjects with limited criminal procedural capacity;

- to specify the rights of participants in criminal proceedings from among socially vulnerable persons;

- to grant public authorities of criminal procedure legal relations with obligations correlating these rights;

- to provide additional guarantees to ensure the exercise of the rights of persons with disabilities;

3) to formalize a procedural mechanism for the realization of the rights and obligations of participants in criminal proceedings, including measures of a coercive nature in case of their non-compliance or improper observance.

Modern Russian conditions do not offer scientifically sound and proven recommendations to ensure the rights of participants in criminal proceedings from among persons with disabilities. As a result, the disabled participants in criminal proceedings are in practice limited in the exercise of their procedural rights. In this regard, we believe that it is necessary to conduct a fullscale scientific study of the issues outlined in this paper.

\section{Conclusion}

The current level of development of human rights concepts and approaches to understanding the essence of the social and legal state demonstrates the need to improve the national legislation in order to achieve the international and European quality of the social value of law in this area $[23,24]$. In particular, this applies to Russian criminal procedure legislation, where the sociovalue approach to the consolidation of mechanisms for the implementation of the legal status of participants in criminal proceedings was not properly reflected in scientific research, and, as a result, did not receive adequate normative consolidation.
In this regard, we believe that:

- it is necessary to recognize socially vulnerable categories of persons (persons with disabilities) as the participants with special legal status in criminal proceedings;

- the scientific and practical study of this subject is important with the aim of doctrinally filling the content of the special criminal procedure status of persons with disabilities, testing it in practice and legislating it in order to ensure them equal opportunities for the realization and protection of their rights and legitimate interests in criminal proceedings (compensatory approach) ;

- the application of a compensatory approach in Russian criminal procedure legislation to participants in criminal proceedings from among persons with disabilities is a manifestation of the social value of this branch of law;

- international law should be a reference point for states, given its role and importance for the development of the national legislation. It is therefore necessary at the international level to adopt a universal international convention, as discussed in the previous paragraph, which should contain the basic definitions, as well as the basis of the legal status of persons of this category and guarantees for its implementation. This will contribute to the uniformity of the legal regulation of these issues throughout the world community, thereby ensuring respect for the rights of these persons.

The further development of this area should already be reflected in the norms of the national legislation taking into account the historical, economic, legal and other characteristics of individual states. In this regard, by analogy with the international law, basic legal acts should be adopted, which should reflect a conceptual approach to the regulation of socially significant issues further developing in the norms of sectoral and other legislation.

\section{References}

1. S.M. Kurbatova, L.V. Bertovsky, Protecting the rights of persons with disabilities as a constitutional value, Advances in Social Science, Education and Humanities Research, 498 (2020)

2. M.S. Balayants, Fundamental legal values of modern society: candidate dissertation (Moscow, 2007)

3. O.V. Martyshin, Problem of values in the theory of state and law, State and law, 10, 5 (2004)

4. D.P. Kommers, Constitutional jurisprudence of the Federal Republic of Germany, 2-nd ed., rev. and expanded (Durham; London, 1997)

5. R. Dworkin, Taking Rights Seriously (Cambridge, 1977)

6. M. J. Perry, Constitution, the Courts, and Human Rights (New Haven, Yale University Press, 1982)

7. Barak, Purposive interpretation in law (Transl. from the Hebrew by S. Bashi) (Princeton; Oxford, Princeton univ. press, 2005) 
8. A. Gewirth, Are there any absolute rights? The philosophical quarterly, 31(122), 1-16 (1981)

9. N.I. Lapin, Modernization of basic values of Russians, Sotsis, 5, 5 (1996)

10. N.S. Bondar, Constitution - value-legal basis for resolving social contradictions: In the context of the practice of the Constitutional Court of the Russian Federation, Comparative Constitutional Review, 2, 46-58 (2008)

11. L.D. Voevodin, Legal personality status in Russia (Moscow, INFRA-M-Norma, 1997)

12. S.A. Avakyan, Constitutional law of Russia. In 2 vol. $5^{\text {th }}$ ed., revised and edited. Vol. 1 (Moscow, INFRA-M, 2014)

13. V.E. Chirkin, Constitutional law of foreign countries. $6^{\text {th }}$ ed. (Moscow, INFRA-M, 2010)

14. L.D. Voevodin, Legal personality status in Russia (Moscow, INFRA-M-Norma, 1997)

15. Medical journal. Retrieved from: https://medicalj.ru/symtoms/head/676-narusheniekognitivnyh-funkcij.

16. S.D. Shcherbakov, M.A. Leonova, Influence of society on the formation of man as a person, Humanitarian scientific research, 11, 30 (2017)

17. Quotes by V.G. Belinsky. Retrieved from: http://www.belinskij.kupec.cz/default.aspx?pg=679 43b0f-9d89-4975-a429-d43674de407e.

18. L.V. Karnaushenko, State as a social institute: problems of theoretical and empirical analysis, Society and law, 1(59), 137-140 (2017)
19. O.V. Rodionova, Social state (theoretical and legal aspect): candidate dissertation (St. Petersburg, 2002)

20. S.M. Kurbatova, Formation of a cognitive approach to understanding a person with disabilities at the international legal level and its impact on national law (on the example of Russian criminal procedural legislation), Issues of Russ. and int. law, 9(8-1), (2019)

21. V.P. Shestakov, A.N. Svintsov, Ya.S. Rocheva, Sociological monitoring of the observance of the rights of persons with disabilities within the framework of the UN Convention on the Rights of Persons with Disabilities, Medical and Social Expertise and Rehabilitation, 18(3), 44-46 (2015)

22. S.M. Kurbatova, On the essence of understanding the social state as a means of ensuring the realization of the legal status of persons with limited cognitive abilities (on the example of criminal procedure law), Law and policy, 8, 119-120 (2019)

23. L.V. Bertovsky, International standards of criminal proceedings involving minors and their implementation in modern Russian criminal proceedings, Issues of Russian and International Law, 7(10A), 12-21 (2017)

24. S. M. Trashkova, International legal regulation as a guarantee of the legal status of juvenile suspects accused in criminal proceedings, Kazan Science, 5, 124-127 (2015) 